\title{
The Pedagogical Concept of Student-Centred Learning in the Context of European Higher Education Reforms
}

\author{
Sabine Hoidn, (PhD in Education and Economics) \\ University of St. Gallen, Switzerland
}

doi: 10.19044/esj.2016.v12n28p439 URL:http://dx.doi.org/10.19044/esj.2016.v12n28p439

\begin{abstract}
The increasing gap between the demand and supply of graduates with high-level qualifications, i.e. tertiary attainment levels, has been a central driver for curricular higher education reforms in Europe. In the last decade, the Bologna Process has established curricular reforms; however, progress toward the implementation of the pedagogical concept of studentcentred learning in European higher education has been rather slow. This paper reviews the current educational policy context within which European higher education institutions operate. Societal developments and trends as well as curricular reform efforts to facilitate a paradigm and culture shift from teacher-centred learning to student-centred learning are discussed. The paper further outlines major obstacles from the perspectives of faculty and students that continue to hinder the successful and widespread implementation of a student-centred learning approach in higher education practice.
\end{abstract}

Keywords: Student-centred learning, constructivist learning and instruction, curriculum reform, Bologna Process, higher education implementation obstacles

\section{Introduction:}

After a decade of structural and ongoing curricular reforms, the Bologna Process has brought about dramatic changes. Progress has been made in all of the three original Bologna reform areas: the three-cycle system (bachelor/master/doctorate) and higher quality standards are meanwhile the norm across Europe, while a smooth and fair recognition of qualifications and periods of study is implemented to varying degrees (see also Bologna Declaration, 1999; Eurydice, 2012). Yet, a systematic implementation within higher education institutions (HEIs) with adequate stakeholder involvement 
(e.g., instructors, students, employers) remains a key challenge (Crosier \& Parveva, 2013).

For the second Bologna decade up to 2020, student-centred learning (SCL) and the teaching mission of higher education have been identified as higher education priority areas by the ministers responsible for higher education in the countries participating in the Bologna Process (Leuven/Louvain-la-Neuve Communiqué, 2009). In order for European HEIs to become more student-centred learning environments (SCLEs), a paradigm and culture shift from teacher-centred learning and instruction (input focus) in which faculty members transmit knowledge to students, to student-centred learning and instruction (outcome-based learning) in which universities produce learning through student discovery and the construction of knowledge is necessary (Barr \& Tagg, 1995). Such a cultural shift from teacher to student would more likely allow HEIs to provide quality higher education for all, enhance graduate employability, and make the European system of higher education compete with some of the best performing education systems in the world such as the United States' and Canada's (ARWU, 2014; THES, 2014).

There is broad consensus that SCL is rooted in a constructivist view of learning and instruction that puts the student at the heart of the learning process. Core values and assumptions of SCL are: centrality of the learner in defining meaning, scaffolded participation in authentic tasks and sociocultural practices, importance of prior and everyday experiences in meaning construction, and access to multiple perspectives, resources, and representations (Land, Hannafin \& Oliver, 2012). SCL unfolds a broad spectrum of participation-oriented practices that engage individuals in learning deeply. These practices emphasize positive and supportive studentteacher relationships, which enable students to persist and succeed in academic environments that are challenging, relevant, collaborative, studentdirected, and applied to real-life situations (e.g., Autor, in print; Dubs, 2013; European Students' Union [ESU], 2015; Friedlaender et al., 2014; Land et al., 2012; Stanford Center for Opportunity Policy in Education [SCOPE], American Institutes for Research [AIR] \& Education Connection, 2015). So far, progress towards the implementation of the pedagogical concept of SCL in European higher education has been rather slow because structural changes have to be implemented first in a systematic manner to pave the way (e.g., Eurydice, 2012; ESU, 2015).

This paper lays out societal developments and trends that impact the demand and supply of higher education graduates. The humanistic vision of the Bologna Process, the pedagogical concept of SCL and areas for studentcentred curriculum reforms are outlined. After that, obstacles to the implementation of a student-centred approach in higher education practice 
are discussed before conclusions are drawn for the higher education policy context.

\section{Societal developments and trends in Europe}

The European Commission has repeatedly emphasised the European HEIs' role in producing a higher number of graduates to secure a better match between the future demand and supply of people with high-level qualifications and to leverage the positive effects of high education attainment on employment rates and economic performance and consequently, competitiveness. The following societal developments and trends impact the demand and supply of higher education graduates and have to be taken into account if European HEIs are to widen access to nontraditional learners, improve completion rates and reduce the time required to complete a degree programme.

- Europe's society will continue to age as a result of low fertility and an ongoing reduction of adult mortality. Population projection trends suggest that demographic changes lead to a higher proportion of elderly people (60 years old and over) and a shrinking labour force (15-59 year olds). The share of people older than 60 years has tripled from 94 million (1950) to 287 million (2013) and will increase further in the coming decades, reaching 417 million in 2050 (United Nations, 2013). The number of young people in Europe has declined steadily between 1990 and 2009. In 1990 about 200 million people in the EU were under 30 years old as compared to 172 million in 2009 (35\% of the total population in the EU-27). EU population projections indicate a further decline until 2020 with about 165 million people under 30 years old (European Commission, 2011a).

- In 2012, the rate of early school leavers in education and training (population aged 18-24 years with at most lower secondary education) in Europe was $12.7 \%$ (about one in eight young people) - showing a slight decrease from the previous year, when it was $13.4 \%$. Males as well as the foreign-born population are at higher risk of being early school leavers as compared to their respective counterparts (European Commission, 2013). Moreover, by 2013 about 65\% of young people (aged 20-24 with females outperforming males) of the EU28-population had completed upper secondary level and postsecondary non-tertiary education, well short of the Education and Training 2010 benchmark of at least 85\% of young people that should have completed upper secondary education (European Commission, 2011a; Eurostat, n.d.).

- The tertiary education participation rate of students studying in the EU27 increased by 22.3\% to reach over 19.4 million between 2000 and 2009, an average annual growth rate of $2.3 \%$ per year (European 
Commission, 2011b). In 2013, there were 19.6 million tertiary students in the EU-28 (Eurostat, n.d.). Enrolment in tertiary education for the 1834 years old increased by a third between 1999 and 2009 across all 47 EHEA (European Higher Education Area) countries, reflecting the continuing move towards the "massification" of higher education, although the growth in participation rates was uneven across countries (Eurydice, 2012).

- The total number of graduates in the EU28 has reached $37.9 \%$ of individuals aged 30 to 34 in 2014, compared to 32.3\% in 2009 and 23.6\% in 2002 with a significant gender difference in favour of women. Approximately 4.8 million students graduated from tertiary education institutions in the EU-28 in 2013 (European Commission, 2013; Eurostat, n.d.; Eurydice, 2013). On average nearly a third of tertiary students fail to successfully complete their programme. While low completion rates can have several reasons (e.g., lack of individual resources, wrong subject/programme choice, attractive employment opportunities), they may also indicate that higher education is not meeting the needs of a diverse student population, has process inefficiencies and lacks a studentcentred approach in designing and delivering programmes (NESET, 2013; OECD, 2014).

- Heterogeneous student body: Despite a substantial expansion of the European higher education system in the past, non-traditional learners (e.g., adult learners, students with disabilities, students from lower socioeconomic groups, children of immigrants, older learners, part-time students) continue to be under-represented in universities (European Commission, 2011b; Van Vught, 2009). It has been suggested that to widen participation and to allow for lifelong learning and social cohesion, European HEIs have to open up to other types of learning and learners, diversify their education programmes, allow for alternative access routes to higher education and for the possibility to obtain qualifications through lifelong learning (Eurydice, 2013).

- Changing skill demands: The demand for manual labour and basic cognitive skills is declining, while there is an increasing demand for a more educated labour force with complex communication and advanced analytical skills. The overall demand for people with high-level qualifications is projected to rise by 13.5 million, while the demand for medium-level qualifications is projected to rise by around 5 million. The demand for people with low-level, or no qualifications is expected to decrease by around 10 million (Cedefop, 2012). It is projected that in 2025 around $44.1 \%$ of employed people will be in a highly-skilled job, compared to $36.5 \%$ in 2000 (Cedefop, 2013). the European Commission (2013) has emphasised the education 
institutions' responsibility for delivering higher education reforms in order to unleash the enormous potential of European universities so that they can fulfil their important educational roles in today's knowledge society and economy.

\section{Curriculum reform: Student-centred learning and the Bologna Process}

In their policy reports and proposals, higher education policy makers such as the European Commission (2008a, p. 4) submit that "traditional teaching approaches based on direct instruction or lecturing are no longer adequate" and that they have to be "replaced by more learner-focused models that are based on the learner's active involvement in the process of reflection and interpretation”. In their meeting in Bucharest in 2012, the ministers set out the following priority for 2012-2015: "Establish conditions that foster student-centred learning, innovative teaching methods and a supportive and inspiring working and learning environment" (Bucharest Communiqué, 2012, p. 5).

The Bologna Process has entered a more in-depth consolidation and operationalisation phase with the second decade. However, both the interest in and implementation of the Bologna Process seem to have stagnated for the past few years; participants of the latest bi-annual meeting of the Bologna Follow-up Group in Athens in 2014 have underscored the need to rethink and improve the Bologna Process in order to adequately address the quantity and quality of higher education graduates. The priority to enhance the quality and relevance of learning and teaching was reiterated in the Yerevan Communiqué (2015, p. 2): "We will encourage and support higher education institutions and staff in promoting pedagogical innovation in student-centred learning environments (...)”.

This section focuses on curriculum reform in general (Bologna Process) and on the pedagogical concept of SCL in higher education in particular. Below, the humanistic vision of the Bologna Process and characteristics of the pedagogical concept of SCL as outlined in policy proposals are introduced. After that, four areas for student-centred curriculum reforms are extracted based on the literature review in order to facilitate the implementation of SCLEs.

\section{The humanistic vision of the Bologna Process}

Higher education is considered to be a public good and responsibility in the European Higher Education Area (Bucharest Communiqué, 2012). The kind of higher education offered today will largely determine the kind of society that will exist tomorrow, i.e., what an "educated person" knows, is able to do and what values guide her/him (Bergan, 2006). A broad humanistic vision indicates that higher education is more than an instrument 
for employability and has a twofold social and economic role to play in the knowledge society and economy of the 21st century: preparing a diversity of students for their professional life and fostering their personal development for better lives and active citizenship in democratic societies (Council of the European Union, 2009). Four major purposes of higher education can be identified in order for HEIs to provide lifelong access to learning that supports the professional and personal objectives of a diversity of learners (Bergan, 2006).

- Preparation for the labour market is the purpose that has been most dominant in public discourse on education and many discussions have been framed in economistic and employability terms (e.g., World Bank, OECD). Employers argue that many current European education systems do not provide students with sufficient preparation for the labour market. HEIs can provide their graduates with a good balance of subject specific and transversal competences and with opportunities to update these competences continuously to adapt to societal changes.

- Preparation for life as active citizens in a democratic society: democracy depends on the active participation of educated citizens. Education at all levels plays a pivotal role in developing a democratic culture and equipping all members of society with knowledge, skills, attitudes and values so that they are able to actively participate in a democratic society. HEIs can contribute to develop a democratic culture through their educational practice, their extracurricular activities and through how they act as institutions.

- Developing and maintaining a broad, advanced knowledge base: this aspect was especially addressed by the Berlin Communiqué. Knowledge has to be both advanced and broad as the knowledge base that is needed in the future is not yet known. Maintaining and developing advanced knowledge from basic and applied research in a broad variety of disciplines as well as the facilitation of knowledge construction and skills in the context of scientific research training (e.g., doctoral studies), are core tasks of HEIs in this regard.

- Personal development: choosing a study programme according to one's interests, intellectual curiosity and the desire to learn are important intrinsic motivating factors that contribute to lifelong personal development. A holistic education aims to educate informed citizens who play an active role in shaping their social and economic environment. Bergan (2006, p. 13) points out that this aspect of higher education has not been explicitly addressed in the context of the Bologna Process; however, is crucial for the humanistic vision underlying the Bologna Process. 
In a nutshell, a more holistic higher education "should include sustainable employment, but it should also extend to citizenship, personal development and our collective knowledge base” (Bergan, 2006, p. 20; Bologna Working Group on Qualifications Frame- works, 2005).

\section{The pedagogical concept of student-centred learning}

SCL has increased in prominence at the European level over the past decade when the importance of the teaching mission of higher education was repeatedly underlined (Leuven/Louvain-la-Neuve Communiqué, 2009; Bucharest Communiqué, 2012; Yerevan Communiqué, 2015). The pedagogical concept of SCL aims to help students to "develop the competences they need in a changing labour market and will empower them to become active and responsible citizens" (Leuven/Louvain-la-Neuve Communiqué, 2009, p. 1). Hence, curriculum reforms that promote SCL entail a curricular and pedagogical renewal and mean "that the teacher's role should shift from imparting knowledge to guiding the student in his or her own learning” (EU-High Level Group, 2013, p. 40). A cultural shift from an input-focused teaching paradigm to an outcome-based learning paradigm changes the roles of teachers and learners and has important implications for the design of learning environments (European University Association [EUA], 2010). Student-centred approaches place students at the centre of their design, implementation and quality assurance and consider students as "partners actively engaged in the development of their university's approach to learning” (Million+ group of post-92 institutions, 2012, p. 6). SCL conveys the notion of students as constructivist learners and active participants with shared responsibilities for outcomes (EUA, 2010).

In the context of the Bologna Process, SCL is commonly characterised as follows (EUA, 2010, pp. 31-32): is:

- Shift in focus from the teacher and what is taught, to the learner and what is learned;

- Different relationship between teacher and learner with the responsibility for learning being shared and the learning being 'negotiated;' the teacher becomes a facilitator;

- Students' particular backgrounds, experiences, perceptual frameworks, learning style and needs are taken into account;

- The learners 'construct' their own meaning by proactive learning, discovery and reflection. The teacher builds critical thinking as part of the learning process;

- There is often a stress on interdisciplinarity with the goal of attaining higher level, generic skills and knowledge;

- The learner is involved in determining what is learned; 
- The learning process is not just or primarily about transfer and restitution of knowledge, but about deeper understanding and critical thinking (e.g., an understanding of the parameters and the provisional nature of knowledge).

- Assessment is generally formative, and feedback continuous;

- A student-centred approach makes it easier to develop blended teaching models and to recognize prior learning, thus benefiting both traditional and non-traditional learners and providing the flexibility to learn throughout life.

Although the Bologna tools (e.g., course credits, modularisation, learning outcomes) and instruments (e.g., qualifications frameworks, quality assurance) are mostly, formally in place, the progress towards the pedagogical concept of SCL in a lifelong perspective has been slow so far because the new degree structure and the supporting tools had to be implemented first and their successful implementation depends on using them in a systematic way (e.g., Eurydice, 2013; ESU, 2015).

\section{Areas for student-centred curriculum reforms in higher education}

The implementation of the Bologna Process has shown that higher education curricula often lag behind the changing needs of individuals, society and the economy (EUA, 2010). The following four extracted curricular reform areas have repeatedly emerged in the context of the political discussion surrounding the implementation of the pedagogical concept of SCL in higher education. It is proposed that these areas need to be taken into consideration by curriculum developers, administrators and managers alike to improve the quality of learning and instruction in HEIs.

High-level learning outcomes: Higher education has to ensure that graduates with the right level of knowledge and skills leave tertiary education. HEIs have to equip students with high-level subject-specific know how as well as transversal competences and skills such as problem solving, teamwork and self-regulated learning. The ability to apply knowledge and skills flexibly in diverse contexts (adaptive expertise) is of utmost importance in today's knowledge society and economy (De Corte, 2013). Thereby, reformulating study programmes in terms of learning outcomes, that is "what a learner knows, understands and is able to do on completion of a learning process” (European Commission, 2008b, p. 11), represents a major cultural shift. Learning outcomes can help students to manage their course expectations and studies better and provide employers with a better understanding of graduates' knowledge and skills (Bologna Working Group on Qualifications Frameworks, 2005; ESU, 2015).

Innovative (student-centred) teaching and learning methods: To provide quality education to students and to combat dropout rates, adequate teaching 
and learning as well as assessment methods are required in higher education (European Council and Commission, 2010). The Council of the European Union therefore supports "the adoption of student-centred approaches to teaching and learning, acknowledging the needs of a diverse student body and promoting a greater variety of study modes” (2011, p. 7). A studentcentred approach goes along with empowering learners, applying effective teaching and learning methods (e.g., problem-based learning), using new information technologies thoughtfully and offering tailored support and guidance structures (European Students' Union [ESU] \& Education International [EI], 2010a, b).

Measures of professional faculty development together with academic counseling facilities and accessible management information systems are crucial for the successful implementation of a SCL approach. Academic development programmes can help new and experienced instructors to adopt SCL approaches that are different from what they themselves experienced as students and assist them in developing new teaching and learning resources. Thereby instructors themselves should be trained in a way that is studentcentred so that they can experience this pedagogical approach as learners and reflect on their experiences before they implement this approach in their courses. HEIs can improve their faculty services by collaborating with instructors who are willing to develop their pedagogical (content) knowledge and skills and to experiment with new teaching methods, fine-tune them over time and create a forum for instructors to share their concerns, good practices, problems experienced and solutions applied (e.g., ESU and EI, 2010a, b; ESU, 2015).

Student support services involving guidance and counseling have been underemphasised by policy makers so far. Yet, a coherent institutional offer of student services during the pre-admission phase, study phase and end of study phase is crucial to cater to an increasingly diversified student body if learning is to become more modularised, flexible and personalised (ESU, 2010; EUA, 2010). Counseling and tutoring provisions can help potential and current students to deal with the challenges that an institutional shift to SCL entails (e.g., communicating the benefits of the educational reform). Learning centers can offer (extra-) curricular courses that foster the development of self-regulated learning of students. In this way student services can help to widen access, improve student retention, prepare students for employment and support students' entry into the labour market (EUA, 2010, 2015). In addition, libraries can provide "multiple places and spaces for learning for students with the highest possible degree of access to information and interaction with others." (ESU \& EI, 2010a, p. 44) The availability of new technologies on campus provides added flexibility to 
where and how learning can take place and can enhance students' learning experiences (ESU \& EI, 2010a).

So far, European HEIs have put structures and various tools and instruments in place to improve the quality of their programmes. However, HEIs still face major obstacles to the implementation of a student-centred approach in higher education practice. SCL requires first and foremost a change in mindset and behaviour on the part of the students and the instructors who are the ones who have to enact the SCL approach in their respective classrooms (e.g., ESU \& EI, 2010b).

\section{Obstacles to the implementation of a student-centred approach in higher education practice: Faculty's perspectives}

Instructors, the main group responsible for designing and bringing to life SCL in their respective classrooms, are important drivers for change. Instructional reforms have to begin with faculty members' efforts to change with the coordinated help of students, faculty developers, academic administrators, and education researchers. Yet, faculty members are often reluctant to embrace calls for educational reforms. Brickner (1995, cited in Ertmer, 1999, p. 48) distinguishes between (1) first-order barriers to change, that is barriers to incremental adjustments of the current practice (e.g., extrinsic factors such as insufficient time to plan instruction, inadequate support), and (2) second-order barriers to change, that is, intrinsic factors that include beliefs about learning and teaching, established classroom practices and unwillingness to change. Provisions to implement a student-centred approach can be undermined by these barriers.

\section{First-order barriers to change}

First-order barriers to change are especially visible in times of deteriorating conditions for academic work. The capacity saturation of European universities and the student- instructor ratio are already problematic because of rising enrolment rates. Due to the massification of higher education, academics face an increase in general workload, particularly bureaucratic tasks and teaching workloads, while tertiary investment and job security decrease at the same time (Jones, 2006). In addition, a trend towards more business-like structures in higher education seems to be accompanied by an erosion of academic freedom for faculty in terms of curricula, teaching, assessment and research topics that hinders change efforts (e.g., EI, 2010; ESU \& EI, 2010b).

Implementing SCL may not be economical in larger university courses. Potential difficulties of using active forms of learning such as blended learning or small-group work in large classes include limited class time, a possible increase in class preparation time, an inadequate physical 
environment (e.g., lecture halls), and a lack of required materials, equipment and resources (Bonwell \& Eison, 1991; EUA, 2010). The teaching workloads of faculty are already demanding and redesigning courses in line with a student-centred approach requires faculty development and a considerable amount of time and effort on the part of the instructors as well as faculty support (e.g., grading) (ESU \& EI, 2010b).

Moreover, current recruitment and promotion policies favour research productivity over teaching quality. Thus, devoting time to student-centred teaching methods may be inhibited due to a higher interest in research than in teaching and is unlikely to be seen as a high priority by faculty given that achievements in research are of greater importance in terms of an academic career (Lea, Stephenson \& Troy, 2003). Teaching in a new way would require faculty to focus more on teaching, further their pedagogical (content) knowledge and, at the same time, fulfil the requirements to pursue a research career. In order to emphasise the importance of the teaching mission of HEIs, career structures would have to provide more opportunities for faculty to develop as teachers and give proper due to achievements in teaching (e.g., teaching awards, funding).

\section{Second-order barriers to change}

The motivation, time and energy of faculty to develop new curricula and further their teaching skills to deliver high-quality teaching may be rather limited. Resistance to instructional change can stem from faculty beliefs with regard to teaching and learning along with a certain understanding of their role as well as discomfort and anxiety created by change (Bonwell \& Eison, 1991). Prosser and Trigwell (1999) submit that instructors with teacher-focused conceptions of teaching hold quite different views about student learning as compared to instructors with student-focused conceptions of teaching. Research on teacher training has shown that instructors' belief systems about the processes of learning and instruction and about the role that students play in these processes are crucial with regard to their teaching practice and the implementation of reforms. Instructors have considerable freedom in choosing the pedagogical approach they apply and whether or not and to which degree they integrate reform initiatives such as new instructional methods into their classroom practice their personal beliefs therefore constitute a major influence (e.g., Baumert \& Kunter, 2006; Pauli \& Reusser, 2011; Turner, Christensen \& Meyer, 2009).

In the light of a strong tradition of telling as teaching, a move toward more student-centred approaches in higher education involves the risk that students will not participate or learn sufficient content, that faculty lose some of their control and are criticized by colleagues or administrators for teaching in alternative ways, or receive poor end-of-term appraisals by students 
(Bonwell \& Eison, 1991). Changes associated with adopting instructional methods that emphasise student participation can seem frightening to instructors familiar with direct instruction due to a lack of knowledge about and experience with student-centred approaches. They might feel intimidated by the challenges of learning new teaching methods and may fear that they devote too much time to teaching which reduces the time they have for research and/or their credibility as researchers and - so far - successful instructors (Handelsman et al., 2004). The high average age of the current teaching staff can further lead to senior faculty members transferring significant levels of responsibility for teaching to younger staff members resulting in senior faculty growing more and more distant from students (EUA, 2010).

Designing SCLEs requires pedagogical (content) knowledge in addition to subject matter knowledge to provide students with tailored help to learn. Faculty might be overwhelmed by the challenges that developing studentcentred curricula and teaching methods pose and lack the necessary pedagogical (content) knowledge (e.g., to provide just-in-time guidance for both individual students and the whole class toward deep learning) (Geven \& Attard, 2012). HEIs and faculty alike may fail to realise the necessity to upgrade instructors' pedagogical skills on a regular basis. Finally, faculty members are often unaware of education research on the effectiveness of SCL and teaching, or they distrust or dismiss such research due to different epistemological assumptions or conflicting research results.

\section{Obstacles to the implementation of a student-centred approach in higher education practice: Students' perspectives}

Students' expectations as well as their perceptions of the learning and teaching context have to be taken into account as important yardsticks in the development of SCLEs (Biggs \& Tang, 2011; Prosser \& Trigwell, 1999). SCL might fail to meet students' expectations of higher education with the instructor as knowledge transmitter or "the sage on the stage". Students are more used to teacher-focused approaches and often lack familiarity with the term SCL and thus, may reject the student-centred approach as frightening. Student perceptions of SCL can vary greatly across and within HEIs and depend on diverse factors such as personal preferences, the subject matter, capabilities and prior experiences (ESU \& EI, 2010b). Prior bad experiences with methods associated with SCL such as group work or project work can result in student resistance to student-centred approaches. Students may feel anxious in terms of what is expected from them, lack motivation or fear that they are being left to themselves without much guidance from the instructor. Students have to gradually be prepared to take greater responsibility for their own learning with the instructor discussing with them the theoretical ideas 
and practical implications of implementing SCL to help them understand the benefits of this approach (e.g., Lea et al., 2003).

Student motivation and interest are also relevant to a student-centred pedagogical practice since motivational and emotional factors influence students' engagement in cognitive learning activities. Research shows that students' psychological needs such as perceived autonomy, competence and social relatedness are important factors that have to be accounted for as they influence the learning process greatly (Ryan \& Deci, 2002). The opportunity to formulate meaningful personal learning objectives and the flexibility to pursue different learning paths are ways to engage students in deep learning processes (Boekaerts, 2003; Maclellan, 2008; Pintrich and Schunk, 2002).

In addition, research indicates that students conceptions of learning are highly relevant to the effectiveness of learning environments insofar as surface learners prefer to be told what to do and what to think, whereas deep learners are primarily concerned with understanding, for example (Entwistle \& Peterson, 2004; Marton, Hounsell \& Entwistle, 1997; Ramsden, 2003; Richardson, 2011).

Moreover, the acquisition of transferable skills such as learning skills and problem-solving skills are crucial for students to become self-regulated learners and problem solvers (Author, 2010). Instructors can help students to acquire these skills by offering them a variety of cognitively activating learning activities and new forms of assessment (e.g., portfolios, peer- and self-assessment) in the context of a rich SCLE that enables students to practice self-regulation and often includes the use of new technologies to facilitate communication and collaboration.

\section{Conclusion: SCL and European higher education policy}

The previous discussion stresses that HEIs have to further increase and widen participation and graduation rates (i.e., access and success in higher education) by attracting more students from both traditional and nontraditional backgrounds. Major European reform initiatives such as the Bologna Process have developed framework conditions that are designed to promote quality higher education (e.g., three-cycle degree structure, learning outcomes, qualifications frameworks). So far, progress towards the implementation of the pedagogical concept of SCL has been rather slow because structural changes have to be implemented first in a systematic manner to pave the way.

Apart from that, HEIs are confronted with diverse implementation obstacles that result from inadequate stakeholder involvement, insufficient funding, deteriorating working conditions for academics, rigid career structures, entrenched values and beliefs and academic traditions, as well as from students' teacher-centred expectations and conceptions of learning, 
among others. Overall, the enormous potential of European HEIs to fulfil their crucial role in developing a collective knowledge base, equipping students for their professional life, fostering their personal development for a better life, and preparing them for active citizenship in democratic societies in the knowledge society and economy of the $21^{\text {st }}$ century is not fully harnessed.

The ministers in their Bucharest and Yerevan Communiqués recommitted to step up efforts already under way to "promote studentcentred learning in higher education, characterised by innovative methods of teaching that involve students as active participants in their own learning” (Bucharest Communiqué, 2012, p. 2) and they stressed their willingness to work together with institutions, students and faculty to facilitate a supportive and inspiring working and learning environment. This paper proposes that HEIs have to continue to engage in curricular and pedagogical renewal to ensure that not only more graduates, but graduates with the right level of subject-based know how and transversal competences and skills leave tertiary education.

In focusing on curriculum reform to promote the implementation of the pedagogical concept of SCL in European higher education, this paper has carved out four areas that are of particular relevance for curriculum reform: high-level learning outcomes, innovative (student-centred) teaching and learning methods, professional faculty development and support, and student support services. HEIs have to take these curricular reform areas as well as potential obstacles from the faculty's and students' perspectives into account in order to further improve the quality of higher education learning and instruction. 


\section{References:}

1. Academic ranking of world universities (ARWU) (2014). Center for World-Class Universities at Shanghai Jiao Tong University. Retrieved, August 20, 2016 from http://www.shanghairanking.com/ ARWU2014.html

2. Author, S. (2010). Lernkompetenzen an Hochschulen fördern. Dissertation an der Universität St. Gallen. Wiesbaden: VS Verlag für Sozialwissenschaften.

3. Author, S. (in print). Student-centred learning environments in higher education classrooms. New York: Palgrave Macmillan.

4. Barr, R. B. \& Tagg, J. (1995). From teaching to learning - a new paradigm for undergraduate education. Change, 27(6), 12-25.

5. Baumert, J. \& Kunter, M. (2006). Stichwort: Professionelle Kompetenz von Lehrpersonen. Zeitschrift für Erziehungswissenschaft, 9(4), $469-520$.

6. Bergan, S. (2006). Promoting new approaches to learning. EUA Bologna Handbook, Article B_1.1-1. Berlin: Raabe Verlag.

7. Biggs, J. B. \& Tang, C. (2011). Teaching for quality learning at university (4th edition). Berkshire: Open University Press.

8. Boekaerts, M. (2003). Toward a model that integrates motivation, affect, and learning. British Journal of Educational Psychology Monograph, Series II(2), 173-189.

9. Bologna Declaration (1999). The Bologna Declaration of 19 June 1999. Retrieved, August 20, 2016 from http://www.magna-char ta.org/resources/files/BOLOGNA_DECLARATION.pdf

10. Bologna Working Group on Qualifications Frameworks (2005). A framework for qualifications of the European Higher Education Area. Copenhagen: Ministry of Science, Technology and Innovation. Retrieved, August 20, 2016 from http://www.ond.vlaanderen.be/ho geronderwijs/bologna/documents/050218_QF_EHEA.pdf

11. Bonwell, C. C. \& Eison, J. A. (1991). Active learning: Creating excitement in the classroom. Washington, DC: George Washington Univ. Retrieved, August 20, 2016 from http://files.eric. ed.gov/full text/ED340272.pdf

12. Bucharest Communiqué (2012). Making the most of our potential: Consolidating the European Higher Education Area. Retrieved, July 20, 2016 from http://www.ehea.info/cid101043/ministerial-conferen ce-bucharest-2012.html

13. Cedefop (2012). Future skills supply and demand in Europe. Forecast 2012. Research paper, no. 26. Retrieved, August 20, 2016 from http://www.cedefop.europa.eu/EN/Files/5526_en.pdf 
14. Cedefop (2013). Roads to recovery: Three skill and labour market scenarios for 2025. Briefing note. Retrieved, August 20, 2016 from http://www.cedefop.europa.eu/EN/Files/9081_en.pdf

15. Council of the European Union (2009). Council conclusions of 12 May 2009 on a strategic framework for European cooperation in education and training ('ET 2020'). Official Journal of the European Union, C 119/2. Retrieved, August 20, 2016 from http://eurlex.europa.eu/LexUriServ/LexUriServ.do?uri=OJ:C:2009:119:0002:0 010:en:PDF

16. Council of the European Union (2011). Council conclusions on the modernisation of higher education. 3128th Education, Youth, Culture and Sport Council meeting Brussels, 28 and 29 November 2011. Retrieved, August 20, 2016 from http://www.consilium.europa.eu/ uedocs/cms_data/docs/pressdata/en/educ/126375.pdf

17. Crosier, D. \& Parveva, T. (2013). The Bologna Process: Its impact on higher education development in Europe and beyond. Paris, UNESCO: International Institute for Educational Planning. Retrieved, August 20, 2016 from http://unesdoc.unesco.org/images/ 0022/002206/220649e.pdf

18. De Corte, E. (2013). Constructive, self-regulated, situated, and collaborative learning: An approach for the acquisition of adaptive competence. Journal of Education, 192(2/3), pp. 33-47.

19. Dubs, R. (2013). Übergänge zwischen Instruktion und Konstruktion. In A. Fischer \& D. Frommberger (Hrsg.), Vielfalt an Übergängen in der beruflichen Bildung - Zwölf Ansichten (S. 227-242). Baltmannsweiler: Schneider Hohengehrn.

20. Entwistle, N. \& Peterson, E. R. (2004). Learning styles and approaches to studying. In C. Spielberger (ed.), Encyclopedia of applied psychology (pp. 537-542). New York, NY: Academic Press.

21. Ertmer, P. A. (1999). Addressing first- and second-order barriers to change: Strategies for technology integration. Educational Technology Research and Development, 47(4), 47-61.

22. EU-High Level Group on the Modernisation of Higher Education (2013). Improving the quality of teaching and learning in Europe's higher education institutions. Report to the European Commission. Retrieved, August 20, 2016 from http://ec.europa.eu/education/hig her-education/doc/modernisation_en.pdf

23. European Commission (2008a). Proposal for a decision of the European Parliament and of the Council concerning the European year of creativity and innovation (2009). COM(2008) 159 final. Retrieved, July 20, 2016 from http://eurlex.europa.eu/LexUriServ/ LexUriServ.do?uri=COM:2008:0159:FIN:EN:PDF 
24. European Commission (2008b). The European Qualifications Framework for Lifelong Learning (EQF). Retrieved, August 20, 2016 from http://www.ond.vlaanderen.be/hogeronderwijs/bologna/news/E QF_EN.pdf

25. European Commission (2011a). Progress towards the common European objectives in education and training. Indicators and benchmarks 2010/11. Commission staff working document. Retrieved, August 20, 2016 from http://aei.pitt.edu/42903/1/SEC_(2011) -526.pdf

26. European Commission (2011b). Commission working document on recent developments in European higher education systems. SEC(2011) 1063 final. Retrieved, August 20, 2016 from http://eurlex.europa.eu/LexUriServ/LexUriServ.do?uri=SEC:2011:1063:FIN:E $\mathrm{N}: \mathrm{PDF}$

27. European Commission (2013). Education and Training Monitor 2013. Retrieved, August 20, 2016 from http://ec.europa.eu/education/ library/publications/monitor13_en.pdf

28. European Council and Commission (2010). Joint progress report of the Council and the Commission on the implementation of the 'Education \& Training 2010 work programme'' Retrieved, August 20, 2016 from http://register.consilium.europa.eu/pdf/en/10/st05/st05 394.en10.pdf

29. European Students' Union (ESU) (2010). Bologna at the finish line. An account of ten years of European higher education reform. Retrieved, August 20, 2016 from http://www.ond.vlaanderen.be/ho geronderwijs/bologna/2010_conference/documents/BAFL_online.pdf

30. European Students' Union (ESU) (2015). Overview on studentcentred learning in higher education in Europe. Retrieved, August 20, 2016 from http://pascl.eu/wp-content/uploads/Overview-on-Stu dent-Centred-Learning-in-Higher-Education-in-Europe.pdf

31. European Students' Union (ESU) \& Education International (EI) (2010a). Time for a new paradigm in education: Student-centred learning toolkit. Retrieved, August 20, 2016 from http://www.esuonline.org/pageassets/projects/projectarchive/100814-SCL.pdf

32. European Students' Union (ESU) \& Education International (EI) (2010b). Student centered learning. An insight into theory and practice. Retrieved, August 20, 2016 from http://www.esu-online.org/ pageassets/projects/projectarchive/2010-T4SCL-Stakeholders-Forum -Leuven-An- Insight-Into-Theory-And-Practice.pdf

33. European University Association (EUA) (2010). Trends 2010: A decade of change in European higher education (by Andrée Sursock 
\& Hanne Smidt). Retrieved, August 20, 2016 from http://www.eu a.be/Libraries/Publications_homepage_list/Trends2010.sflb.ashx

34. Eurostat (n.d.). Online database. Retrieved, August 20, 2016 from http://ec.europa.eu/eurostat/data/database

35. Eurydice (2012). The European Higher Education Area in 2012: Bologna Process implementation report. Retrieved, August 20, 2016 from http://eacea.ec.europa.eu/education/eurydice/documents/themati c_reports/138EN.pdf

36. Eurydice (2013). Education and Training in Europe 2020. Retrieved, August 20, 2016 from http://eacea.ec.europa.eu/education /Eurydice/ documents/thematic_reports/163EN.pdf

37. Friedlaender, D., Burns, D., Lewis-Charp, H., Cook-Harvey, C. M., Zheng, X., \& Darling-Hammond, L. (2014). Student-centered schools: Closing the opportunity gap. Stanford, CA: Stanford Center for Opportunity Policy in Education.

38. Geven, K. \& Attard, A. (2012). Time for student-centred learning? In A. Curaj, P. Scott, L. Vlasceanu \& L. Wilson (eds.), European higher education at the crossroads (pp. 153-172). Amsterdam, The Netherlands: Springer.

39. Handelsman, J., Ebert-May, D., Beichner, R., Bruns, P., Chang, E., DeHaan, R., Gentile, J., Lauffer, S., Stewart, J., Tilghman, S. M., \& Wood, W. B. (2004). Scientific teaching. Science, 304(5670), 521522.

40. Jones, G. A. (2006). The restructuring of academic work: Themes and observations. Higher Education in Europe, 31(3), 317-325.

41. Land, S. M., Hannafin, M. J., \& Oliver, K. (2012). Student-centered learning environments: Foundations, assumptions, and design. In D. H. Jonassen \& S. M. Land (eds.), Theoretical foundations of learning environments (pp. 3-25). New York, NY: Routledge.

42. Lea, S. J., Stephenson, D., \& Troy, J. (2003). Higher education students' attitudes to student centred learning: Beyond 'educational bulimia’. Studies in Higher Education, 28(3), 321-334.

43. Leuven/Louvain-la-Neuve Communiqué (2009). The Bologna Process 2020 - The European Higher Education Area in the new decade. Communiqué of the Conference of European Ministers responsible for higher education, 28-29 April 2009. Retrieved, August 20, 2016 from http://www.ond.vlaanderen.be/hogeronderwijs/ bologna/conference/documents/leuven_louvain-la-neuve_communiqu é april 2009.pdfín

44. Maclellan, E. (2008). The significance of motivation in studentcentred learning: A reflective case study. Teaching in Higher Education, 13(4), 411-421. 
45. Marton, F., Hounsell, D., \& Entwistle, N. (eds.) (1997). The experience of learning: Implications for teaching and studying in higher education. Edinburgh: Scottish Academic Press.

46. Million+ group of post-92 institutions (2012). Teaching that matters. London. Retrieved, August 20, 2016 from https://www.academia.ed u/3100153/Teaching_that_Matters

47. Network of Experts on Social Aspects of Education and Training [NESET] (2013). Drop-out and completion in higher education in Europe: Supporting students from under-represented groups. Retrieved, August 20, 2016 from http://nesetweb.eu/wpcontent/uploads/ 2015/09/2013-Drop-out-and-Completion-in-Higher-Education-in-Eur ope-among-students-from-under-represented-groups.pdf

48. O’Neill, G. \& McMahon, T. (2005). Student-centered learning: What does it mean for students and lecturers? In G. O’Neill, S. Moore, \& B. McMullin (eds.), Emerging issues in the practice of university learning and teaching (pp. 27-36). Dublin: AISHE.

49. OECD (2014). Education at a glance 2014. OECD indicators. Paris: OECD Publishing.

50. Pauli, C. \& Reusser, K. (2011). Expertise in Swiss mathematics instruction. In Y. Li \& G. Kaiser (eds.), Expertise in mathematics instruction. An international perspective (pp. 85-107). New York, NY: Springer.

51. Pintrich, P. \& Schunk, D. (2002). Motivation in education. Upper Saddle River, NJ: Prentice- Hall Merrill.

52. Prosser, M. \& Trigwell, K. (1999). Understanding learning and teaching: The experience in higher education. London: Society for Research in Higher Education \& Open University Press.

53. Ramsden, P. (2003). Learning to teach in higher education (2nd edition). London: Routledge. Richardson, J. T. E. (2011). Approaches to studying, conceptions of learning and learning styles in higher education. Learning and Individual Differences, 21(3), 288-293.

54. Ryan, R. M. \& Deci, E. L. (2002). An overview of self-determination-theory: An organismic- dialectical perspective. In E. L. Deci \& R. M. Ryan (eds.), Handbook of self-determination research (pp. 3-33). Rochester, NY: University of Rochester Press.

55. Stanford Center for Opportunity Policy in Education (SCOPE), American Institutes for Research (AIR), \& Education Connection (2015). Centered on results: Assessing the impact of student-centred learning. Quincy, MA: Nellie Mae Education Foundation. Retrieved September 01, 2016 from https://edpolicy.stanford.edu/publications/ pubs/1348 
56. Times Higher Education Supplement (THES) (2014). The world university rankings 2013-2014. Retrieved, August 20, 2016 from http://www.timeshighereducation.co.uk/world-university-rankings/20 13-14/world-ranking

57. Turner, J. C., Christensen, A., \& Meyer, D. K. (2009). Teachers' beliefs about student learning and motivation. In L. J. Saha \& A. G. Dworkin (eds.), International handbook of research on teachers and teaching (pp. 361-371). Boston: Springer.

58. United Nations (2013). World population ageing 2013. Retrieved, Au gust 20, 2016 from https://www.un.org/en/development/desa/populat ion/publications/pdf/ageing/WorldPopulationAgeingReport2013.pdf

59. Van Vught, F. (2009). The EU innovation agenda: Challenges for European higher education and research. Higher Education Management and Policy, Vol. 21/2 (pp. 1-22). Paris: OECD.

60. Yerevan Communiqué (2015). [Not title]. Retrieved, August 20, 2016 from http://bologna- yerevan2015.ehea.info/files/YerevanCom muniqueFinal.pdf 